\title{
PENGGUNAAN KOMBINASI AUKSIN DAN SITOKININ UNTUK MENGINDUKSI \\ TUNAS PADA KULTUR JARINGAN SENGON (Falcataria moluccana) MENGGUNAKAN BAGIAN KOTILEDON
}

Combination of auxin and cytokinin on shoot initiation by tissue culture of Falcataria moluccana using cotyledon segment

Toni Herawan dan Burhan Ismail

Balai Besar Penelitian Bioteknologi dan Pemuliaan Tanaman Hutan

J. Palagan Tentara Pelajar Km. 15, Purwobinangun, Pakem, Sleman, Yogyakarta 55582

Telp. (0274) 895954, 896080, Fax. (0274) 896080

\begin{abstract}
The purpose of this research is to examine the effect of auxin (NAA) and cytokinin (BAP) on shoot initiation in tissue culture of sengon (Falcataria moluccana) using cotyledon segment. Cotyledon segments were collected from aseptic seedlings. Cotyledon segments were aseptically cultured on a Murashige and Shoog's (MS) medium containing different concentrations of Benzyl-amino-purine (BAP) ranging from 1 to $3 \mathrm{mg} / \mathrm{l}$ and Naphtalene-acetic-acid (NAA) ranging from 0,01 to 0,03 $\mathrm{mg} / \mathrm{l}$. Result of analysis of variance indicates that plant growth regulator of BAP and NAA had significant effect on shoot formation up to 4 months age. The subsequent Duncan Multiple Range Test indicates that concentration of BAP $3 \mathrm{mg} / \mathrm{l}$ and $N A A 0,03 \mathrm{mg} / \mathrm{l}$ gave best effect on shoot formation. Combination of plant growth regulator of BAP at concentration of 1,2 and $3 \mathrm{mg} / 1$ with $\mathrm{NAA}$ at concentration of $0,01,0,02$ and $0,03 \mathrm{mg} / \mathrm{l}$ gave no significant effect on shoot formation and shoot growth.
\end{abstract}

Key Words : Shoot initation, cotyledon, growth regulator

\begin{abstract}
ABSTRAK
Tujuan penelitian adalah untuk mengetahui pengaruh penggunaan kombinasi zat pengatur tumbuh auksin yaitu NAA (Napthalene-acetic-acid) dan sitokinin yaitu BAP (Benzyl-amino-purine) pada tahap awal induksi sengon dan mengetahui perbandingan konsentrasi zat pengatur tumbuh NAA dan BAP yang tepat untuk menginduksi tunas pada tahap awal kultur jaringan sengon. Bagian kotiledon diperoleh dari kecambah steril sengon. Bagian kotiledon sengon dikulturkan dalam media Murashige dan Skoog's (MS) yang mengandung zat pengatur tumbuh Benzyl-amino-purine (BAP) dengan konsentrasi 1 sampai $3 \mathrm{mg} / \mathrm{l}$ dan zat pengatur tumbuh Napthalene-acetic-acid (NAA) dengan konsentrasi 0,01 sampai $0,03 \mathrm{mg} / \mathrm{l}$; dan 1 taraf perlakuan sebagai kontrol. Hasil analisis sidik ragam menunjukkan bahwa zat pengatur tumbuh BAP dan NAA berpengaruh nyata terhadap pembentukan
\end{abstract}


jumlah tunas sengon pada umur 4 bulan, kemudian hasil uji DMRT menunjukkan bahwa konsentrasi BAP $3 \mathrm{mg} / \mathrm{l}$ dan NAA $0,03 \mathrm{mg} / \mathrm{l}$ memberikan respon yang paling baik terhadap pembentukan jumlah tunas sengon. Kombinasi zat pengatur tumbuh BAP pada konsentrasi 1, 2 dan $3 \mathrm{mg} / 1$ dengan NAA pada konsentrasi $0,01,0,02$ dan $0,03 \mathrm{mg} / 1$ tidak memberikan respon terhadap pertumbuhan panjang tunas dan pembentukan jumlah tunas sengon.

\section{Kata Kunci : Induksi tunas, kotiledon, zat pengatur tumbuh}

\section{PENDAHULUAN}

Sengon (Falcataria moluccana) merupakan salah satu jenis tanaman yang diprioritaskan untuk Hutan Tanaman Industri (HTI). Jenis ini mudah tumbuh dan tidak menuntut persyaratan tumbuh yang banyak serta memiliki prospek dalam pemanfaatan kayunya. Pada umur 6 tahun jenis ini sudah mampu menghasilkan kayu bulat sebesar $156 \mathrm{~m}^{3} / \mathrm{Ha}$. Kayunya banyak digunakan untuk peti kemas, bahan pembungkus, bahan mainan, perabot rumah tangga, sebagai bahan pembuat pulp (Anonim, 1992).

Kelemahan dari jenis ini adalah rentan terhadap serangan hama penggerek batang yang disebut boktor (Xystrocera festiva) dan penyakit karat tumor, penyakit ini disebabkan oleh jamur Uromycladium tepperianum yang menyerang bagian batang, cabang, maupun titik tumbuh terminal dan lateral tanaman. Tanaman yang diserang jamur ini pada umumnya mulai dari tanaman di persemaian maupun tanaman yang sudah dewasa di lapangan. Akibat serangan hama dan penyakit tersebut menyebabkan pertumbuhan tanaman tidak sempurna (Anonim, 2009a).
Di sisi lain kayu sengon merupakan jenis yang serbaguna sehingga banyak ditanam oleh masyarakat khususnya di Pulau Jawa. Hutan rakyat sengon mempunyai pengaruh ganda yang sangat menguntungkan bagi petani, di samping memberikan manfaat kayu dan hasil ikutannya yang dapat memberikan manfaat secara ekonomi, juga bermanfaat sebagai fungsi hidrologis, suplai oksigen, estetika, dan keindahan lingkungan (Anonim, 2009b).

Walaupun sengon telah lama dibudidayakan oleh masyarakat Indonesia, dalam pengembangannya belum mampu meningkatkan produktivitasnya. Hal ini disebabkan karena kendala serangan hama dan penyakit baik yang disebabkan oleh hama boktor maupun karat tumor. Sebab lain karena pola tanam yang cenderung monokultur, sehingga keragaman genetik sengon di hutan rakyat sangat rendah (Seido et al., 1993).

Penyediaan benih unggul sengon yang berasal dari areal produksi benih, tegakan benih, dan kebun benih masih terbatas. Upaya propagasi jenis ini secara konvensional baik secara stek maupun cangkok belum banyak berhasil (Anonim, 2009c). Begitu pula dengan propagasi secara kultur jaringan yang menggunakan materi 
vegetatif (eksplan) yang berasal dari pohon dewasa, juga masih mengalami kendala dalam hal masih tingginya tingkat kontaminasi dan rendahnya hasil induksi (Anonim, 1995). Untuk menanggulangi permasalahan tersebut dilakukan penelitian kultur jaringan menggunakan eksplan dari bagian kotiledon, hal ini disebabkan karena bagian kotiledon merupakan jaringan yang masih muda dan kandungan auksinnya masih tinggi, sehingga akan menunjang potensi tingkat perbanyakannya (Suhardi, dkk., 2000). Dalam penelitian ini juga digunakan penggunaan kombinasi auksin dan sitokinin dalam berbagai konsentrasi larutan. Sitokinin dan auksin merupakan dua kelompok hormon pada tanaman yang sangat penting dan diperlukan dalam kegiatan kultur jaringan. Fungsi auksin untuk merangsang pemanjangan sel, pembentukan kalus, dan pertumbuhan akar. NAA merupakan salah satu golongan auksin sintetis yang sifatnya stabil, karena tidak mudah terurai oleh enzimenzim yang dikeluarkan oleh sel atau oleh pemanasan pada proses sterilisasi. Sedangkan sitokinin telah terbukti dapat menstimulir terjadinya pembelah-an sel, proliferasi kalus, pembentukan tunas, mendorong proliferasi meristem ujung, meng-hambat pembentukan akar serta mendorong pembentukan klorofil pada kalus (Santoso dan Nursandi, 2002). BAP merupakan salah satu golongan sitokinin yang mempunyai sifat lebih stabil, lebih murah, lebih tersedia dan yang paling penting yaitu lebih efektif dibanding dengan kinetin. BAP mendorong pembentukan kalus dan sekaligus dapat merangsang munculnya tunas dari kalus yang terbentuk.
Tujuan penelitian ini adalah untuk mengetahui pengaruh penggunaan kombinasi zat pengatur tumbuh auksin yaitu NAA (Napthaleneacetic-acid) dan sitokinin yaitu BAP (Benzylamino-purine) pada tahap awal induksi sengon, dan mengetahui perbandingan konsentrasi zat pengatur tumbuh NAA dan BAP yang tepat untuk menginduksi tunas pada tahap awal kultur jaringan sengon dari bahan kotiledon.

\section{BAHAN DAN METODE}

\section{A. Lokasi}

Penelitian ini dilaksanakan di laboratorium Kultur Jaringan Balai Besar Penelitian Bioteknologi dan Pemuliaan Tanaman Hutan (B2PBPTH), Yogyakarta. Penelitian dimulai pada bulan Mei 2007 s/d September 2007.

\section{B. Bahan dan Alat}

Bahan yang digunakan dalam penelitian ini yaitu benih sengon yang dikecambahkan dalam medium Murashige \& Skoog's tanpa penambahan zat pengatur tumbuh (MS nol) yang selanjutnya diambil bagian kotiledonnya, Media MS (terdiri dari unsur hara makro, unsur hara mikro, vitamin MS, bahan pemadat berupa agar, dan sukrosa. Komposisi bahan terlampir. Alat-alat yang digunakan antara lain adalah oven, lemari es, timbangan analitik, hot plate dengan magnetik stirrer, dan laminar air flow cabinet.

\section{Metode Penelitian}

Metode yang digunakan dalam penelitian ini adalah Rancangan Acak Lengkap (RAL) yang disusun oleh 3 taraf perlakuan zat pengatur tumbuh (ZPT) BAP, 3 taraf perlakuan zat peng- 
atur tumbuh (ZPT) NAA, dan 1 taraf sebagai kontrol, untuk jelasnya diuraikan di bawah ini.

Faktor perlakuannya yaitu :

1. Konsentrasi 6-Benzyl-amino-purine (BAP)

$$
\begin{aligned}
& \mathrm{B} 1=\text { konsentrasi } 1 \mathrm{mg} / \mathrm{l} \\
& \mathrm{B} 2=\text { konsentrasi } 2 \mathrm{mg} / 1 \\
& \mathrm{~B} 3=\text { konsentrasi } 3 \mathrm{mg} / 1
\end{aligned}
$$

2. Konsentrasi Napthalene-acetic-acid (NAA)

$$
\begin{aligned}
& \mathrm{N} 1=\text { konsentrasi } 0,01 \mathrm{mg} / 1 \\
& \mathrm{~N} 2=\text { konsentrasi } 0,02 \mathrm{mg} / 1 \\
& \mathrm{~N} 3=\text { konsentrasi } 0,03 \mathrm{mg} / 1
\end{aligned}
$$

3. Kontrol = tanpa penambahan $\mathrm{BAP}$ maupun NAA dalam medium MS $\left(\mathrm{B}_{0} \mathrm{~N}_{0}\right)$.

Masing-masing perlakuan diulang 3 kali. Tiap ulangan dibuat 10 tabung percobaan. Jadi untuk semua perlakuan ada 300 tabung percobaan kultur.

Sebelum diinduksi benih direndam dalam air panas $\pm 100^{\circ} \mathrm{C}$ selama satu malam, lalu ditiriskan, selanjutnya di dalam laminar air flow cabinet direndam dalam larutan hidrogen peroksida $\left(\mathrm{H}_{2} \mathrm{O}_{2}\right) 7 \%$ selama 15 menit, lalu ditiriskan. Selanjutnya dibilas larutan alkohol $70 \%$ selama 0,5 - 1 menit, sebelum ditanam dibilas akuades steril 3 kali. Benih yang sudah disterilisasi selanjutnya ditanam satu per satu ke dalam medium MS. Selanjutnya media yang sudah ditanami diinkubasi pada suhu $24^{\circ} \mathrm{C}$ dengan kelembaban rata-rata $70 \%$ dalam rak-rak di ruang kultur dengan penyinaran lampu TL selama 16 jam/hari.

Pengamatan yang dilakukan meliputi :

1. Panjang tunas
Pengamatan panjang tunas diukur dari titik tumbuh sampai ujung tunas dengan satuan sentimeter $(\mathrm{cm})$.

2. Jumlah tunas

Pengamatan dilakukan terhadap pembentukan tunas. Tunas yang muncul dihitung jumlahnya.

Pengamatan dilakukan satu minggu dua kali. Pada tahap induksi tunas membutuhkan waktu 4 minggu.

Data hasil pengamatan panjang tunas dan jumlah tunas disusun dalam tabel kemudian semua data dianalisa dengan analisis Rancangan Acak Lengkap (RAL). Jika ternyata hasil perhitungan menunjukkan ada beda nyata selanjutnya dilakukan pengujian dengan uji DMRT pada taraf 5\%.

\section{HASIL DAN PEMBAHASAN}

\section{A. Hasil Penelitian}

\section{Panjang Tunas}

Pengukuran perkembangan panjang tunas sengon sampai dengan umur 4 minggu yang menggunakan 3 taraf perlakuan zat pengatur tumbuh BAP, 3 taraf perlakuan zat pengatur tumbuh NAA, dan 1 taraf perlakuan sebagai kontrol disajikan pada Tabel 1.

Hasil analisis sidik ragam panjang tunas sengon umur 4 minggu menunjukkan bahwa faktor konsentrasi ZPT BAP, faktor konsentrasi ZPT NAA, dan kontrol, serta inter-aksi antara BAP dengan NAA tidak berpengaruh terhadap pertumbuhan panjang tunas sengon. 


\section{Jumlah Tunas}

Pengukuran pembentukan jumlah tunas sengon sampai dengan umur 4 minggu yang menggunakan 3 taraf perlakuan zat pengatur tumbuh BAP, 3 taraf perlakuan zat pengatur tumbuh NAA, dan 1 taraf perlakuan sebagai kontrol disajikan pada Tabel 2.

Hasil sidik ragam menunjukkan bahwa ada beda nyata di antara perlakuan konsentrasi zat pengatur tumbuh BAP dan konsentrasi zat pengatur tumbuh NAA terhadap pembentukan jumlah tunas sengon, sedangkan kombinasi diantaranya tidak memberikan pengaruh yang nyata. Analisis untuk perlakuan BAP dan NAA dilanjutkan menggunakan uji DMRT, yang hasilnya dapat dilihat pada Tabel 3 dan Tabel 4.

Hasil uji DMRT pada Tabel 3 memperlihatkan bahwa antara perlakuan konsentrasi BAP $3 \mathrm{mg} / 1$ dengan perlakuan konsentrasi BAP 2 mg/l tidak ada beda nyata, antara perlakuan konsentrasi BAP $3 \mathrm{mg} / 1$ dan konsentrasi BAP 2 $\mathrm{mg} / \mathrm{l}$ dengan perlakuan konsentrasi BAP $1 \mathrm{mg} / \mathrm{l}$ dan kontrol ada beda nyata, kemudian antara perlakuan konsentrasi BAP $1 \mathrm{mg} / \mathrm{l}$ dengan kontrol ada beda nyata. Dari Tabel 3 diketahui bahwa perlakuan dengan menggunakan konsentrasi BAP $3 \mathrm{mg} / 1$ adalah yang terbaik terhadap pembentukan jumlah tunas sengon.

Hasil uji DMRT pada Tabel 4 diketahui bahwa antara perlakuan konsentrasi NAA 0,03 $\mathrm{mg} / \mathrm{l}$ dengan perlakuan konsentrasi NAA 0,02 $\mathrm{mg} / \mathrm{l}$, konsentrasi NAA $0,01 \mathrm{mg} / 1$, dan kontrol ada beda nyata. Antara perlakuan konsentrasi NAA $0,02 \mathrm{mg} / 1$ dengan konsentrasi NAA 0,01 $\mathrm{mg} / \mathrm{l}$ tidak beda nyata, sedangkan antara perlakuan konsentrasi NAA $0,02 \mathrm{mg} / 1$ dan konsentrasi NAA $0,01 \mathrm{mg} / 1$ dengan kontrol ada beda nyata. Dari Tabel 4 diketahui bahwa

Tabel 1. Sidik Ragam Panjang Tunas Sengon Umur 4 Minggu

\begin{tabular}{|l|c|c|c|c|c|}
\hline \multicolumn{1}{|c|}{ Sumber Variasi } & db & JK & KT & F Hitung & Sig. \\
\hline Konsentrasi BAP & 2 & 0,250 & 0,125 & $0,407 \mathrm{~ns}$ & 0,671 \\
\hline Konsentrasi NAA & 2 & 1,672 & 0,836 & $2,716 \mathrm{~ns}$ & 0,090 \\
\hline $\begin{array}{l}\text { Konsentrasi BAP x } \\
\text { Konsentrasi NAA }\end{array}$ & 4 & 0,386 & 0,096 & $0,313 \mathrm{~ns}$ & 0,866 \\
\hline Galat & 20 & 6,156 & 0,308 & & \\
\hline Total & 29 & 45,561 & & & \\
\hline
\end{tabular}

Keterangan : ns $=$ non signifikan

* = signifikan

Tabel 2. Sidik Ragam Jumlah Tunas Sengon Umur 4 Minggu

\begin{tabular}{|l|l|l|l|l|l|}
\hline \multicolumn{1}{|c|}{ Sumber Variasi } & db & \multicolumn{1}{|c|}{ JK } & \multicolumn{1}{|c|}{ KT } & $\begin{array}{c}\text { F } \\
\text { Hitung }\end{array}$ & Sig. \\
\hline Konsentrasi BAP & 2 & 51,131 & 25,565 & $14,294^{*}$ & 0,000 \\
\hline Konsentrasi NAA & 2 & 125,782 & 62,891 & $35,164^{*}$ & 0,000 \\
\hline $\begin{array}{l}\text { Konsentrasi BAP x } \\
\text { Konsentrasi NAA }\end{array}$ & 4 & 2,840 & 0,710 & 0,397 & 0,808 \\
\hline Galat & 20 & 35,770 & 1,789 & & \\
\hline Total & 29 & 315,137 & & & \\
\hline
\end{tabular}

Keterangan : ns = non signifikan

* = signifikan 
Tabel 3. Uji DMRT faktor zat pengatur tumbuh BAP dan konsentrasinya terhadap pembentukan jumlah tunas sengon

\begin{tabular}{|c|c|c|c|}
\hline Konsentrasi BAP & N & $\begin{array}{c}\text { Rerata } \\
\text { jumlah tunas }\end{array}$ & Pengelompokan \\
\hline $3 \mathrm{mg} / 1$ & 9 & 10,1500 & $\mathrm{a}$ \\
\hline $2 \mathrm{mg} / \mathrm{l}$ & 9 & 8,5900 & $\mathrm{a}$ \\
\hline $1 \mathrm{mg} / 1$ & 9 & 6,7822 & $\mathrm{~b}$ \\
\hline $0 \mathrm{mg} / 1$ & 3 & 2,4333 & $\mathrm{c}$ \\
\hline
\end{tabular}

Keterangan : Angka yang diikuti huruf yang sama menunjukkan tidak ada beda nyata menurut uji DMRT taraf 5\%

Tabel 4.Uji DMRT faktor zat pengatur tumbuh NAA dan konsentrasinya terhadap pembentukan jumlah tunas sengon

\begin{tabular}{|c|c|c|c|}
\hline Konsentrasi NAA & N & $\begin{array}{c}\text { Rerata } \\
\text { jumlah tunas }\end{array}$ & Pengelompokan \\
\hline $0,03 \mathrm{mg} / 1$ & 9 & 11,4767 & $\mathrm{a}$ \\
\hline $0,02 \mathrm{mg} / \mathrm{l}$ & 9 & 7,6356 & $\mathrm{~b}$ \\
\hline $0,01 \mathrm{mg} / 1$ & 9 & 6,4100 & $\mathrm{~b}$ \\
\hline $0 \mathrm{mg} / 1$ & 3 & 2,4333 & $\mathrm{c}$ \\
\hline
\end{tabular}

Keterangan : Angka yang diikuti huruf yang sama menunjukkan tidak ada beda nyata menurut uji DMRT taraf $5 \%$

perlakuan dengan menggunakan konsentrasi NAA $0,03 \mathrm{mg} / \mathrm{l}$ adalah yang terbaik terhadap pembentukan jumlah tunas sengon.

\section{B. Pembahasan}

Hasil penelitian Hidayat (2007) pada tanaman ulin, menyebutkan bahwa bagian tanaman seperti embrio muda, hipokotil, kotiledon, dan batang muda (bagian meristem) merupakan bagian yang mudah menghasilkan kalus, karena pada jaringan muda terdapat hormon auksin endogen yang dapat merangsang pertumbuhan kalus. Hoesen (2001) yang diperkuat oleh Avivi dan Dewanti (2005) menyatakan bahwa pembentukan organ-organ baru dipengaruhi pula oleh faktor dari sumber eksplannya, auksin dan/atau sitokinin baik yang ada dalam medium maupun yang ada dalam jaringan tanaman (secara endogen). Dalam penelitian ini digunakan eksplan bagian kotiledon, karena diduga kandungan hormon dalam eksplan ini lebih tinggi sehingga pemberian ZPT BAP secara eksogen dapat meningkatkan kemampuan eksplan untuk memproduksi tunas lebih banyak.

Analisis sidik ragam pertumbuhan panjang tunas sengon umur 4 minggu menunjukkan bahwa faktor konsentrasi BAP, faktor konsentrasi NAA, dan kontrol, serta interaksi antara BAP dengan NAA tidak memberikan pengaruh yang nyata. Hasil analisis sidik ragam terhadap pembentukan jumlah tunas sengon umur 4 bulan menunjukkan bahwa faktor zat pengatur tumbuh BAP memberikan pengaruh yang nyata terhadap pembentukan jumlah tunas sengon. Hasil uji lanjut DMRT menunjukkan bahwa konsentrasi BAP $3 \mathrm{mg} / \mathrm{l}$ memberikan respon yang paling baik terhadap pembentukan jumlah tunas sengon, walaupun tidak berbeda nyata dengan konsentrasi BAP 2 mg/l. BAP merupakan Zat Pengatur Tumbuh golongan sitokinin yang mempunyai 
struktur seperti kinetin. Namun BAP mempunyai sifat lebih stabil, lebih murah, lebih tersedia dan yang paling penting yaitu lebih efektif dibanding dengan kinetin. BAP mendorong pembentukan kalus dan sekaligus dapat merangsang munculnya tunas dari kalus yang terbentuk (Sriyanti dan Wijayani, 1994).

Analisis sidik ragam terhadap pembentukan jumlah tunas sengon umur 4 bulan menunjukkan bahwa faktor zat pengatur tumbuh NAA berpengaruh nyata terhadap pembentukan jumlah tunas sengon. Hasil uji lanjut DMRT menunjukkan bahwa konsentrasi NAA $0,03 \mathrm{mg} / 1$ memberikan respon yang paling baik terhadap pembentukan jumlah tunas sengon. Hormon auksin di dalam tubuh tanaman dihasilkan oleh pucukpucuk batang, pucuk-pucuk cabang dan ranting yang menyebar luas ke dalam seluruh tanaman. Auksin dalam konsentrasi tinggi menghambat pertumbuhan mata tunas samping, hal ini membuktikan bahwa penggunaan NAA dengan konsentrasi rendah sudah mampu memacu pembentukan jumlah tunas sengon. Fungsi auksin untuk merangsang pemanjangan sel, pembentukan kalus, dan pertumbuhan akar. NAA merupakan golongan auksin sintetis yang sifatnya stabil, karena tidak mudah terurai oleh enzim-enzim yang dikeluarkan oleh sel atau oleh pemanasan pada proses sterilisasi (Pierik, 1987).

Kombinasi zat pengatur tumbuh BAP pada konsentrasi 1, 2 dan $3 \mathrm{mg} / 1$ yang termasuk dalam golongan sitokinin dengan NAA pada konsentrasi $0,01,0,02$ dan $0,03 \mathrm{mg} / 1$ yang termasuk golongan auksin tidak memberikan respon terhadap pertumbuhan panjang tunas dan pembentukan jumlah tunas sengon. BAP sangat umum digunakan dalam kultur jaringan terutama dalam menumbuhkan tunas. BAP yang termasuk golongan sitokinin tidak akan bekerja tanpa adanya auksin dalam hal ini NAA. Pembentukan tunas meskipun membutuhkan sitokinin pada konsentrasi yang tinggi tetapi membutuhkan auksin pada konsentrasi yang rendah.

Seperti pernyataan di atas, tidak adanya interaksi pada percobaan kali ini mungkin disebabkan oleh kombinasi konsentrasi antara BAP dan NAA yang kurang seimbang. Kemungkinan lain dapat juga disebabkan oleh macam zat pengatur tumbuh yang dikombinasikan kurang tepat mengingat bahwa zat pengatur tumbuh yang termasuk golongan auksin dan sitokinin ada beberapa macam. Meskipun hasil sidik ragam dan hasil uji lanjut DMRT tidak menunjukkan adanya interaksi, namun dari analisis statistik dapat dilihat perlakuan yang paling banyak menginduksi tunas, yaitu perlakuan BAP $3 \mathrm{mg} / 1$ dan NAA $0,03 \mathrm{mg} / 1$.

Jika antara perlakuan dibandingkan dengan kontrol dalam merangsang tunas, medium yang diberi zat pengatur tumbuh memperlihatkan kemampuan menginduksi tunas lebih baik dibandingkan dengan kontrol. Meskipun dari kontrol muncul akar, hal ini tidak terlalu dipermasalahkan sebab pada tahap awal kultur jaringan tujuan utamanya adalah pembuatan kultur dari eksplan yang bebas mikro organisme serta inisiasi pertumbuhan tunas baru (Herawan dan Laksmi, 1996). 


\section{KESIMPULAN}

Berdasarkan hasil analisis dan pembahasan, maka dapat diambil kesimpulan :

1. Penggunaan kombinasi konsentrasi zat pengatur tumbuh BAP dan konsentrasi zat pengatur tumbuh NAA pada tahap awal kultur jaringan Falcataria moluccana tidak berpengaruh nyata terhadap pertumbuhan panjang tunas dan pembentukan jumlah tunasnya.

2. Konsentrasi zat pengatur tumbuh BAP $3 \mathrm{mg} / \mathrm{l}$ dan konsentrasi zat pengatur tumbuh NAA $0,03 \mathrm{mg} / 1$ memberikan respon yang paling baik terhadap pembentukan jumlah tunas sengon ( Falcataria moluccana).

\section{DAFTAR PUSTAKA}

Anonim, 1992. Rencana Kerja Pembiakan Vegetatif Jenis Shorea spp., Paraserianthes falcataria, Pinus merkusii, Eucalyptus deglupta, E. urophylia, Santalum album, Departemen Kehutanan Dirjen Reboisasi dan Rehabilitasi Lahan, Proyek Pusat Pemuliaan Pohon Prop. DIY, Yogyakarta.

Anonim, 1995. Laporan Uji Coba Kultur Jaringan. Departemen Kehutanan Dirjen Reboisasi dan Rehabilitasi Lahan, Proyek Pusat Pemuliaan Pohon Prop. DIY, Yogyakarta.

Anonim, 2009a. Teknik Pencegahan dan Pengendalian Hama, Penyakit, dan Gulma Tanaman Hutan. Balai Besar Penelitian Bioteknologi dan Pemuliaan Tanaman Hutan. Yogyakarta.

Anonim, 2009b. Pemuliaan Untuk Ketahanan Penyakit pada Sengon (Paraserianthes falcataria). Balai Besar Penelitian Bioteknologi dan Pemuliaan Tanaman Hutan. Yogyakarta.

Anonim, 2009c. Pengembangan Teknologi Perbanyakan Vegetatif Makro Sengon (Paraserianthes falcataria). Balai Besar Penelitian Bioteknologi dan Pemuliaan Tanaman Hutan. Yogyakarta.

Avivi, S., dan P. Dewanti. 2005. Teknologi Produksi Bibit Melon (Cucumis melo L.) dengan teknik In-Vitro. Jurnal Ilmu Dasar Vol. 6 No. 1, 2005: 33-40. Fakultas Pertanian Universitas Jember.

Herawan, T. dan Hendrati R.L. 1996. Petunjuk Teknik Kegiatan Kultur Jaringan, Badan Litbang Kehutanan. Balai Penelitian dan Pengembangan Pemuliaan Tanaman Hutan, Yogyakarta.

Hidayat. 2007. Induksi Pertumbuhan Eksplan Endosperm Ulin dengan IAA dan Kinetin. AGRITROP, 26 (4):147-152. Fakultas Pertanian Universitas Udayana, Denpasar.

Hoesen D. S. H. 2001. Perbanyakan dan Penyimpanan Kultur Sambung Nyawa (Gynura procurabes (Leur.) Merr.) Dengan teknik In-Vitro. Berita Biologi. 5 (4) : 379 385 .

Pierik, R.L.M. 1987. In Vitro Culture of Higher Plant. Martinus Nijhoff Publisher, Netherland.

Santoso, U., dan Nursandi. 2002. Kultur Jaringan Tanaman. UMM Press, Malang.

Seido, K., Widyatmoko, and G. Nursinggih. 1993. Preliminary Analysis of Isozyme Variation of Paraserianthes falcataria in 
Indonesia. Proceed. BIO-REFOR,

Yogyakarta. P 122-124.

Sriyanti, K. dan Wijayani, A. 1994. Teknik

Kultur Jaringan. Kanisius, Yogyakarta.

Suhardi, M. Na'iem, B. Radjagukguk, Widaryanti

W.W., E. Faridah., T. Herawan., dan O.

Karyanto. 2000. Pengembangan Aspek

Teknologi Penambatan Nitrogen dan

Mikoriza dalam Kegiatan Penelitian

Paraserianthes falcataria Pada Tanah

Ultisol. Kantor Menteri Negara Riset dan

Teknologi. Dewan Riset Nasional, Jakarta. 